\title{
Effect of Planting Distance on Yield and Agronomic Characteristics of Red Kidney and Native White Beans in an Oxisol ${ }^{1,2}$
}

\author{
J. Badillo-Feliciano, M. A. Lugo-López, and T. W. Scott ${ }^{3}$
}

\begin{abstract}
The effect of planting distance on yield and yield components of two field bean varieties $(27 \mathrm{R}$, a red kidney bean imported from Trinidad, and Bonita, a selected native white bean) were evaluated in a Coto clay, a Tropeptic Haplorthox. Planting distances included 30,45 , and $60 \mathrm{~cm}$ between rows. Mean yield differences between varieties and between planting distances were not significant. However, a field-wide average of around $2200 \mathrm{~kg} / \mathrm{ha}$ was obtained, a satisfactory yield under prevailing conditions. Plant and pod weight did not differ between varieties, but with the $60 \mathrm{~cm}$ distance between rows they were heavier than with $30 \mathrm{~cm}$ and $45 \mathrm{~cm}$. Bonita produced more pods than 27R; the lower number occurred with the $30 \mathrm{~cm}$ distance. Bonita produced an average of 5.5 seeds/pod; $27 R$, only 3.8 . Both varieties appeared to be free of insect or disease damage.
\end{abstract}

\section{INTRODUCTION}

Dry beans offer vast possibilities in the humid and subhumid tropics as an important source of dietary protein. Both the native white bean and the red kidney bean types are favorites in the Puerto Rican diet. They are consumed daily, often twice a day, together with rice. Little is known, however, about their cultivation requirements in tropical environments. In a previous paper, Lugo-López et al. (5) reported on the response of native white beans to $\mathrm{N}$ fertilizers. This and the previously mentioned study on $\mathrm{N}$ fertilization were conducted as part of an overall project to develop a technological package of practices for dry bean production in the deep, well drained, acid, relatively infertile soils of the tropics. Previous experience with other legume crops under Puerto Rico conditions has pointed to the importance of increased plant populations, which under adequate levels of management can lead to increased yields (7).

This paper reports on an experiment conducted to evaluate the effect

${ }^{1}$ Manuscript submitted to Editorial Board April 11, 1977.

2 Joint contribution of the Department of Agronomy, Cornell University, Ithaca, N.Y. and the Agricultural Experiment Station, University of Puerto Rico, Mayagüez Campus, Río Piedras, P.R. This study was part of the investigations supported by the USAID under research contract ta-c-1104 entitled: "Soil fertility in the humid tropics".

${ }^{3}$ Associate Agronomist; Former Professor and Soil Scientist, Agricultural Experiment Station, University of Puerto Rico, Mayagüez Campus, Río Piedras, P.R.; now Consultant, Cornell University; and Professor of Soil Science, Cornell University, Ithaca, N.Y. Appreciation is expressed to Mr. Luis Calduch for his valuable help in some of the field measurements. 
of planting distance on yields and yield components of two field bean types.

\section{MATERIALS AND METHODS}

An experiment was conducted at the Isabela Substation farm on a Coto soil, a Tropeptic Haplorthox, clayey, kaolinitic, isohyperthermic (4), with pH 5.0; CEC, 13 meq, and Ca saturation, 25\%. It is high in $\mathrm{Mn}$ and low in available P. Mean annual rainfall is about $1658 \mathrm{~mm}$. Evaporation from a Class A pan is approximately $6 \mathrm{~mm} /$ day during the summer and $4 \mathrm{~mm} /$ day during the winter. The mean annual maximum temperature is $29.4^{\circ} \mathrm{C}$ while the mean minimum temperature is $18.9^{\circ}$ C. Solar radiation ranges from an average of 300 langleys/day in the winter to 600 in the summer. The elevation is about $122 \mathrm{~m}$ above sea level.

The experiment followed a split-plot design with six replications. Planting distances of main plots were 30,45 , and $60 \mathrm{~cm}$ between rows. The corresponding plant populations were 444,000, 296,000, and 222,000 plants/ha. Subplots were planted with two field bean varieties: $27 R$, a red kidney type, originally from Turrialba, Costa Rica, introduced to Puerto Rico from seedstock from Trinidad; and Bonita, a selection of a native white bean $(3,6)$. Plots were $3.65 \mathrm{~m} \times 1.52 \mathrm{~m}$. Weeds were controlled with a preemergent application of Dacthal $^{4}$ at the rate of $13.5 \mathrm{~kg} / \mathrm{ha}$. The whole field received a blanket application of $1121 \mathrm{~kg} / \mathrm{ha}$ of a 10-10-8 fertilizer prior to planting. Seeds were sown on November 26,1975 . The crop of $27 \mathrm{R}$ was harvested on February 9, 1976, at 75 days of age, and that of native white beans was harvested 8 days later.

Data were taken on dry bean yields, number of seeds/10 pods, weight of 10 plants, and number and weight of pods/10 plants. All data were statistically analyzed.

\section{RESULTS AND DISCUSSION}

Table 1 gives data on yield and other agronomic characteristics for the white and red kidney beans at the three planting distances. There were no significant differences in mean yields between varieties and between the three planting distances. Both produced around $2200 \mathrm{~kg} /$ ha, irrespective of planting distance. These are good yields for $27 \mathrm{R}$ and compare very well with the highest yields (total) i.e., $1100 \mathrm{~kg} / \mathrm{ha}$ reported under the conditions prevailing at Trinidad (2). For Bonita, these yields are excellent (3). In 1944, González-Ríos and Riollano (3)

${ }^{4}$ Trade names are used in this publication solely for the purpose of providing specific information. Mention of a trade names does not constitute a guarantee or warranty of materials by the Agricultural Experiment Station of the University of Puerto Rico or an endorsement over materials not mentioned. 
compared the performance of native white beans at $30 \mathrm{~cm}$ vs. $60 \mathrm{~cm}$ between rows. Plants within the row were spaced at $15 \mathrm{~cm}$. Yield increases between 15 and $45 \%$ were obtained in the closer planting distances.

Beans appear to respond to length of day (3). Evidently the relatively short, cool, and dry days of the winter season at Isabela favored growth, flowering, pod development, and seed production in both types of beans.

TABLE 1. -Yield and other agronomic characteristics of red kidney and native white beans grown on an Oxisol

\begin{tabular}{|c|c|c|c|c|}
\hline \multirow{2}{*}{ Variety } & \multicolumn{4}{|c|}{ Values for indicated parameter at indicated planting distance ${ }^{1}$} \\
\hline & $30 \mathrm{~cm}$ & $45 \mathrm{~cm}$ & $60 \mathrm{~cm}$ & Mean \\
\hline \multicolumn{5}{|c|}{ Yields, $\mathrm{kg} / \mathrm{ha}$} \\
\hline $27 \mathrm{R}$ & 2224 & 2188 & 2136 & 2183 \\
\hline Bonita & 2316 & 2306 & 2181 & 2268 \\
\hline Mean & 2270 & 2247 & 2158 & 2225 \\
\hline \multicolumn{5}{|c|}{ Seed/10 pods, no. } \\
\hline $27 \mathrm{R}$ & $37 a^{2}$ & $39 \mathrm{a}$ & $38 \mathrm{a}$ & $38 \mathrm{a}$ \\
\hline Bonita & $56 \mathrm{~b}$ & $53 \mathrm{~b}$ & $57 \mathrm{~b}$ & $55 \mathrm{~b}$ \\
\hline Mean & 46 & 46 & 48 & 47 \\
\hline \multicolumn{5}{|c|}{ Weight of 10 plants, $g$} \\
\hline $27 \mathrm{R}$ & 165 & 213 & 270 & 216 \\
\hline Bonita & 154 & 174 & 275 & 201 \\
\hline Mean & $159 \mathrm{~b}$ & $193 \mathrm{~b}$ & $272 \mathrm{a}$ & 208 \\
\hline \multicolumn{5}{|c|}{ Weight of pods 110 plants, $g$} \\
\hline $27 \mathrm{R}$ & 119 & 146 & 188 & 148 \\
\hline Bonita & 103 & 130 & 210 & 151 \\
\hline Mean & $111 \mathrm{~b}$ & $138 \mathrm{~b}$ & 199 a & 149 \\
\hline \multicolumn{5}{|c|}{ Pods 110 plants, no. } \\
\hline $27 \mathrm{R}$ & $49 \mathrm{~d}$ & $56 c$ & $64 \mathrm{~b}$ & $56 \mathrm{a}$ \\
\hline Bonita & $88 \mathrm{c}$ & $115 \mathrm{~b}$ & $140 \mathrm{a}$ & $114 \mathrm{~b}$ \\
\hline Mean & 68 & 85 & 102 & 83 \\
\hline
\end{tabular}

${ }^{1}$ Only sets of values where there are significant differences are lettered.

${ }^{2}$ Values in columns, and rows followed by the same letter do not differ significantly at the $5 \%$ level according to Duncan's multiple range test. Lettered values are compared vertically for varieties and horizontally for mean planting distances.

The varieties did not differ significantly as to the weight of 10 plants and pod weight, but in both cases pod and plant weight at $60 \mathrm{~cm}$ were heavier than those at either 45 or $30 \mathrm{~cm}$. Mean differences were highly significant.

Bonita produced significantly more pods than $27 \mathrm{R}$. The lower number of pods occurred at the $30 \mathrm{~cm}$ planting. Again, Bonita was by far 
superior to $27 \mathrm{R}$ as to the number of beans/pod ( $55 \mathrm{vs}$. 38), the differences being highly significant. Planting distance did not affect this relationship.

In a previous study, Bastidas-Ramos and Camacho (1), obtained better yields at plant population levels of $220,000 /$ ha as compared to $110,000,126,000$, and 700,000 . They maintain that this level of competition allows plants to make a more efficient use of such inputs as soil moisture, fertility, and light. In these studies, increasing the level of competition between plants led to increased plant height, but yields/ plant and pods/plant decreased.

In general, while plants and pods were heavier and pods more numerous with increasing distances between rows, yields of dry beans of both cultivars remained unaffected. Planting closer is more expensive since more seed is required. However, this reduction in cost may be offset by the more frequent weeding needed as spacing between rows is increased.

\section{RESUMEN}

Dos variedades de habichuelas (27R, colorada tipo diablo, importada de Trinidad y Bonita, una selección nativa de tipo blanco) se compararon en cuanto a rendimientos y sus componentes. Se sembraron a tres distancias entre hileras: 30,45 y $60 \mathrm{~cm}$. La 27R se cosechó a los 75 días y la Bonita, 8 días más tarde. No se registraron diferencias significativas entre variedades ni entre distancias entre hileras. Sin embargo, se obtuvo un rendimiento de alrededor de $2200 \mathrm{~kg}$./ha., rendimiento que se considera satisfactorio dentro de las condiciones en que se realizó el experimento y para los Oxisols, que son suelos profundos, de buen desagüe, ácidos y relativamente infértiles. No hubo diferencias significativas en el peso de las plantas y de las vainas que puedan atribuirse a las variedades, pero sembradas a $60 \mathrm{~cm}$ ambas eran más pesadas que a 30 y a $45 \mathrm{~cm}$. Bonita produjo 5.5 semillas/vaina; 27R, sólo 3.8 . Ambas variedades parecen ser resistentes a enfermedades e insectos que prevalecen en el invierno en Isabela.

\section{LITERATURE CITED}

1. Bastidas-Ramos, G., and Camacho, C. H., 1969. Competencia entre plantas y en el rendimiento y otras características del frijol caraota, Acta Agron. 19(2): 69-88.

2. Gonsalvez, C., 1975. Seed production of red kidney beans (Phaseolus vulgaris) at Chaguaramas Agricultural Development Project, Paper presented at the Annual Meeting of the Caribbean Food Crops Society, Trinidad.

3. González-Ríos, P., and Riollano, A., 1951. El mejoramiento de la habichuela blanca del país (Phaseolus vulgaris) por medio de la selección, Univ. P.R. Est. Exp. Agr. Univ. P.R. Bol. 94, 21 pp.

4. Lugo-López, M. A., and Rivera, L. H., 1976. Taxonomic classification of the soils of Puerto Rico, 1975, Agric. Exp. Stn. Univ. P.R. Bull. 245, 32 pp.

5. Lugo-López, M. A., Badillo-Feliciano, J., and Calduch, L., 1977. Response of native white beans (Phaseolus vulgaris) to various $\mathrm{N}$ levels in an Oxisol, J. Agric. Univ. P.R. 61(4): 438-42.

6. McClelland, T. B., 1918, 1920, 1921, 1922, 1923. Puerto Rico (Mayagüez) Agric. Exp. Stn. Rep. 13.

7. Silva, S., Vincente-Chandler, J., Abruña, F., and Rodríguez, J. H., 1972. Effect of season and plant spacing on yields of intensively managed soybeans under tropical conditions, J. Agric. Univ. P.R. 54(4): 365-9.

8. Spurling, A. T., 1973. Field trials with Canadian Wonder beans in Malawi, Exp. Agric. 9(2): 97-105. 